\title{
A mechanistic model (BCC-PSSICO) to predict changes in the hydraulic properties for bio-amended variably saturated soils
}

Albert Carles Brangarí, $, 1,2$ Xavier Sanchez-Vila, ${ }^{1,2}$ Anna Freixa, ${ }^{3}$ Anna M.

Romaní, ${ }^{3}$ Simonetta Rubol, ${ }^{4}$ and Daniel Fernàndez-Garcia ${ }^{1,2}$

Corresponding author: Albert C. Brangarí, Department of Civil and Environmental Engineering, Universitat Politècnica de Catalunya (UPC), Jordi Girona 1-3, 08034 Barcelona, Spain (albert.carles@upc.edu)

\footnotetext{
${ }^{1}$ Department of Civil and Environmental
} 


\section{Key Points.}

- A new mechanistically-based model to estimate the impact of complex biofilms on the soil hydraulic properties.

- We derive a set of analytical equations for water retention and relative permeability.

- The model is corroborated by using real data from laboratory experiments and previously existing models.

${ }_{4}$ Abstract. The accumulation of biofilms in porous media is likely to in-

5 fluence the overall hydraulic properties and, consequently, a sound under-

standing of the process is required for the proper design and management

Engineering, Universitat Politècnica de

Catalunya (UPC), Jordi Girona 1-3, 08034

Barcelona, Spain.

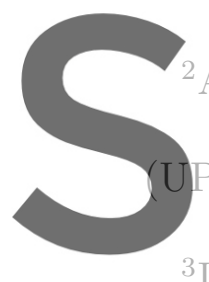

${ }^{2}$ Associated Unit: Hydrogeolo

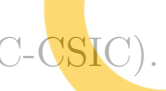

${ }^{3}$ Institute of Aquatic Ecology,
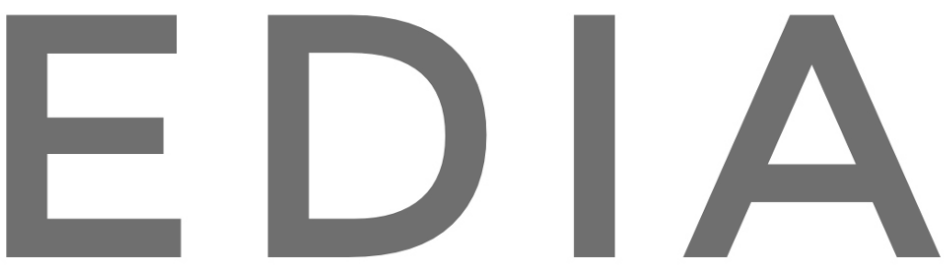

Register for free at https//www.scipedia.com to download the version without the watermark Department of Environmental Sciences,

University of Girona, Campus Montilivi

17071 Girona, Spain.

${ }^{4}$ Department of Biological Sciences,

Marine Environmental Biology Section,

University of Southern California, Los

Angeles, CA 90089, USA. 
7 of many technological applications. In order to bring some light into this phe-

s nomenon we present a mechanistic model to study the variably saturated hy-

9 draulic properties of bio-amended soils. Special emphasis is laid on the dis-

10 tribution of phases at pore-scale and the mechanisms to retain and let wa-

${ }_{11}$ ter flow through, providing valuable insights into phenomena behind bioclog-

12 ging. Our approach consists in modeling the porous media as an ensemble

${ }_{13}$ of capillary tubes, obtained from the biofilm-free water retention curve. This

${ }_{14}$ methodology is extended by the incorporation of a biofilm composed of bac-

terial cells and extracellular polymeric substances (EPS). Moreover, such a

microbial consortium displays a channeled geometry that shrinks/swells with

suction. Analytical equations for the volumetric water content and the rel-

8 ative permeability can then be derived by assuming that biomass reshapes

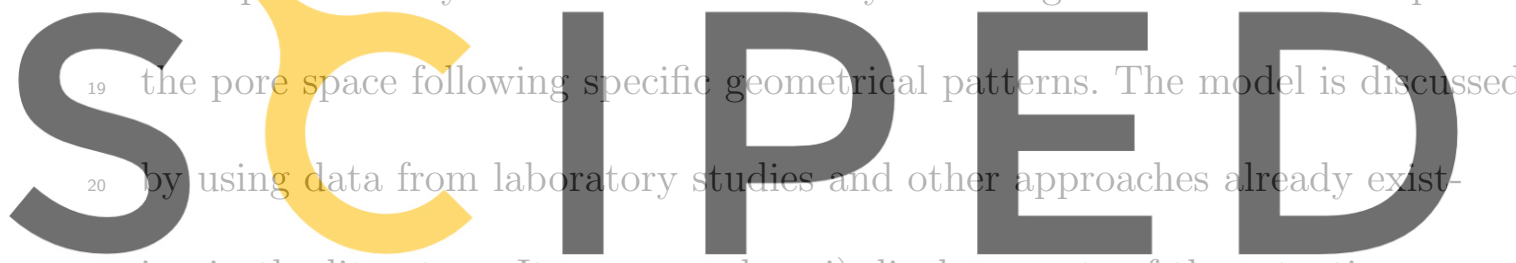

${ }_{21}$ ing in the literature. It can reproduce i) displacements of the retention curve

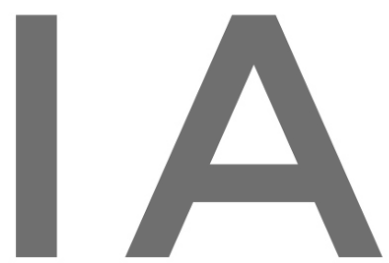

Register for free at https//www.scipedia.com to download the version without the watermark

towards higher saturations and il) permeability reductions of distinct orders

${ }_{23}$ of magnitude. Our findings also illustrate how even very small amounts of

${ }_{24}$ biofilm may lead to significant changes in the hydraulic properties. We there-

${ }_{25}$ fore state the importance of accounting for the hydraulic characteristics of

${ }_{26}$ biofilms and for a complex/more realistic geometry of colonies at the pore-

27 scale. 


\section{Introduction}

The vadose zone is of major interest because of its role in the environment and in

${ }_{29}$ human life [Selker et al., 1999]. The reason why the unsaturated zone is so appealing is

so that it connects different environmental compartments providing water and nutrients to

31 the biosphere. As a result of this interaction, a wide range of bio-mediated processes with

32 potential to modify soil characteristics are triggered [DeJong et al., 2013].

33 In the middle of the twentieth century, engineers and soil scientists started paying attention to the significance of bio-mediated soil processes for the design and management of technological applications. One example where bioclogging has strong implications is the infiltration of water in recharge facilities, characterized by a pro-con dichotomy. On ${ }^{37}$ the one hand, the accumulation of biomass might be considered a disadvantage because
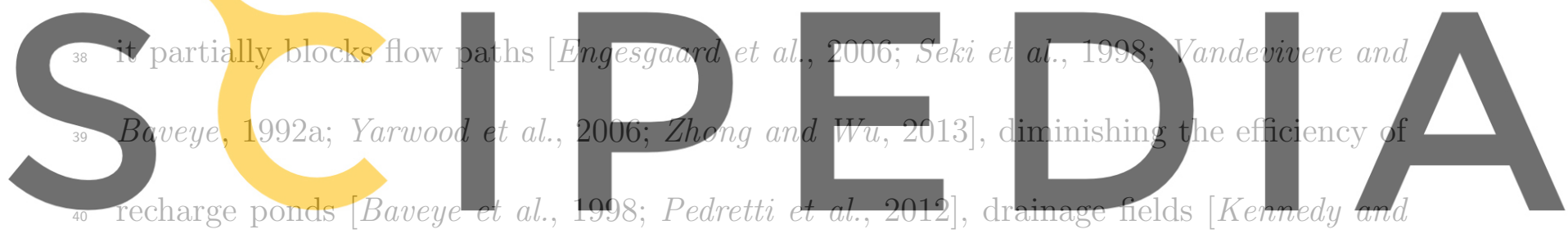

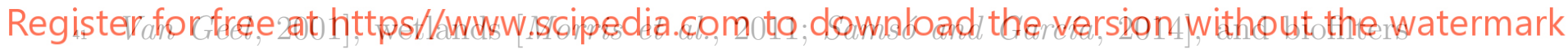

${ }_{42}$ [Mauclaire et al., 2006; Soleimani et al., 2009]. On the other hand, the presence of bacte-

43 rial communities has proved beneficial, as for example, it increases water retention time

${ }_{44}$ [Van Cuyk et al., 2001], eventually facilitating the removal of contaminants [Christensen

45 et al., 2000; Rodríguez-Escales et al., 2016; Zhang et al., 1995]. Moreover, biomass driven

46 permeability reduction may be exploited in geotechnical engineering [Castegnier et al.,

47 2006; Ross et al., 2001], in $\mathrm{CO}_{2}$ sequestration [Cunningham et al., 2009], and in oil recov- 
${ }_{48}$ ery $[$ Abdel-Waly, 2013]. Therefore, whether biomass accumulation proves to be an overall

49 advantage or a drawback depends on the particular circumstances.

${ }_{50} \quad$ The largest and most diverse bacterial population in the biosphere coexists in the vadose

${ }_{51}$ zone [Or et al., 2007a]. Many studies have pointed out the existence of large amounts

${ }_{52}$ of bacteria forming aggregates of cells [e.g., De Beer and Schramm, 1999; Vandevivere

${ }_{53}$ and Baveye, 1992a]. Most bacteria are embedded, to a greater or lesser extent, in a self-

${ }_{54}$ produced matrix forming biofilms attached to soil particles [Fenchel, 2002; Young and

${ }_{55}$ Crawford, 2004]. Such a matrix is composed of a combination of solids [De Muynck et al.,

2010; Ehrlich, 1999], gaseous by-products [Rebata-Landa and Santamarina, 2012; Seki et al., 1998], and extracellular polymeric substances (EPS) [Flemming and Wingender, 2010; Stoodley et al., 2002]. Moreover, biofilm comprises complex structures of intricate

59 strandlike architecture that forms pores, voids and channels [Stewart, 2012; Stoodley et al.,
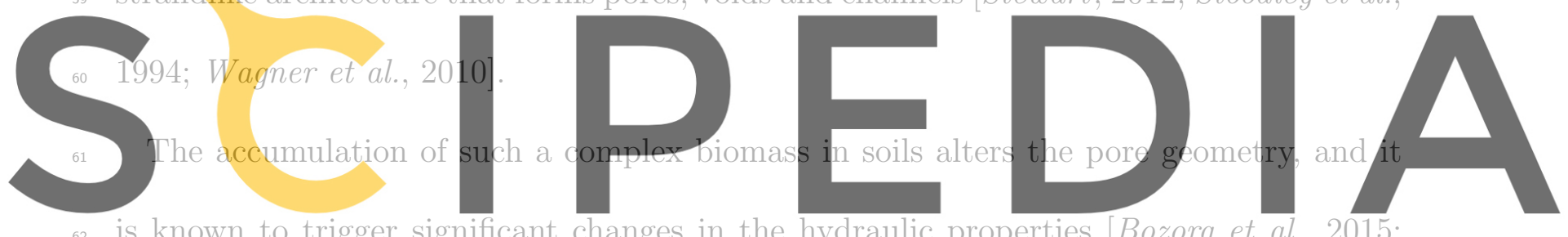

Register for free at https//www.scipedia.com to download the version without the watermark 63 Rockhold et al., 2002; Or et at., 2007a. However, it is difficult to correlate a given biofilm

${ }_{64}$ colonization with such changes. The capacity of microbial communities to dynamically

${ }_{65}$ adapt to the environmental conditions [Kim et al., 2010; Wilking et al., 2011] hampers

${ }_{66}$ the formulation of general models. This highlights the need for a sound understanding of

${ }_{67}$ the components and structure of the microbial community, as well as of their spatial dis-

${ }_{68}$ tribution. A number of strategies with varying degrees of complexity have been adopted

${ }_{69}$ to evaluate the effects of biomass accumulation on the hydraulic properties. Some stud-

70 ies treat biofilm from a macroscopic point of view without assuming a specific pattern. 
${ }_{71}$ Clement et al. [1996] defined analytical expressions to account for porosity and permeabil-

72 ity changes in saturated porous media. Rockhold et al. [2002] presented a composite media

73 model in which these definitions were extended to unsaturated soils. Rosenzweig et al.

${ }_{74}$ [2012] explored the effect of EPS on the soil-water retention curve (SWRC) by using sim-

75 ple superposition. In contrast, some studies aim at describing biofilm and porous media in

76 detail. Early studies modeled biofilm in saturated media as a continuous layer of uniform

77 thickness covering the soil grains [Rittmann, 1993; Taylor et al., 1990; Cunningham et al.,

78 1991] or as discrete microcolonies [Vandevivere and Baveye, 1992a]. Mostafa and Van Geel

\section{[2007, 2012] incorporated the presence of EPS and the distinction between active and inert}

biomass into the impermeable biofilm model. The permeability formulations were based

on the approaches proposed by Burdine [1953] and Mualem [1976]. Meanwhile, Thullner

and Baveye [2008] studied the use of biofilm layers embedded in cylindrical pores, and

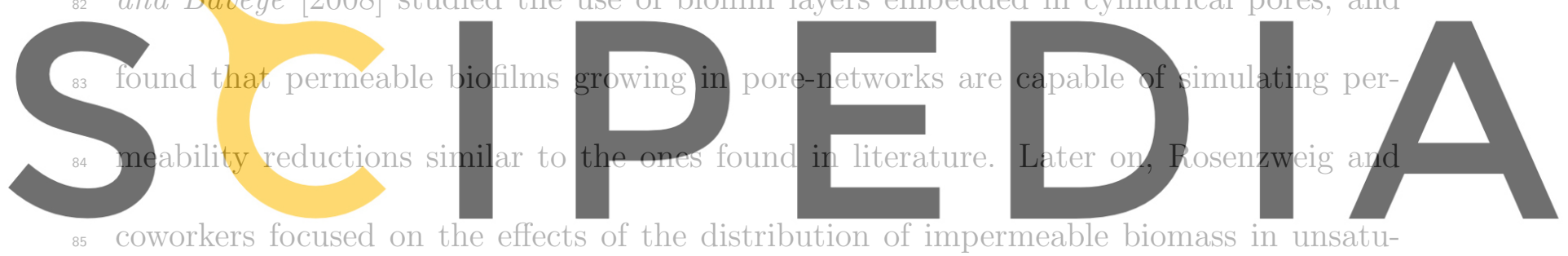

Register for free at https//www.scipedia.com to download the version without the watermark

rated conditions. They assumed that biofims cover the walls of cylindrical capillary tubes

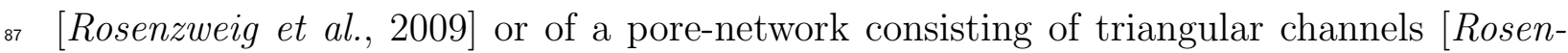

${ }_{88}$ zweig et al., 2013, 2014]. Similarly, Ezeuko et al. [2011] and Qin and Hassanizadeh [2015]

s9 used geometries of increased complexity.

${ }_{90}$ The present study provides a new mechanistic model that simulates the changes in the

${ }_{91}$ SWRC and the relative permeability induced by biofilm accumulation. Soil is represented

${ }_{92}$ as an ensemble of capillary tubes colonized by a complex biofilm. It is well known that

${ }_{93}$ this interpretation does not consider dual-occupancy or connectivity [Likos and Jaafar, 
94

${ }_{95}$ [e.g., Thullner and Baveye, 2008; Mostafa and Van Geel, 2007; Rosenzweig et al., 2009].

${ }_{96}$ For the sake of simplicity it is used here as a first step towards a more realistic represen-

${ }_{97}$ tation of biofilm complexity. The microbial phase in this model has six elements that are

98 synthesized in the acronym PSSICO. Letter "P" stands for Porous, which indicates that

99 the biomass matrix has an internal secondary porosity. "S" denotes Sticking, as we model

100 only the biomass that grows attached to the solids, and not the one remaining in sus-

101

102 changes volume and rheological properties in response to suction by absorbing/exuding

103 water. "I" stands for Identifiable, denoting that the model requires a quantification of biomass from laboratory or field data, or estimated from a model. "C" is referred to the

105 potential presence of biofilm Channels through which water can easily flow or be retained.

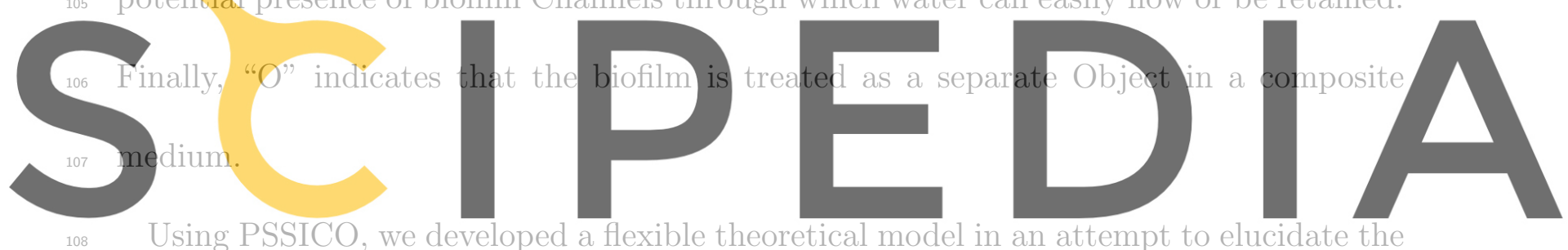

Register for free at https//.www.scipedia.com to download the version without the watermark o9 mechanisms conditioning water retention and flow through bio-amended systems. Distin-

${ }_{110}$ guishing between water in biofilms and in the pore-matrix, a set of analytical equations

${ }_{111}$ for saturation and relative permeability is derived. The model is used then to simulate

${ }_{112}$ the changes in the SWRC observed in two laboratory experiments. The results obtained

${ }_{113}$ are discussed and compared to other biofilm models from the literature. Finally, some

114 conclusions are drawn from the sensitivity analysis of the parameters. 


\section{Conceptual Model}

\subsection{Water in Bio-amended Soils}

${ }_{121}$ volume associated with the microbial phase $\left(\theta_{w, b i o}+\theta_{r, b i o}\right)$ and that of the pore-matrix

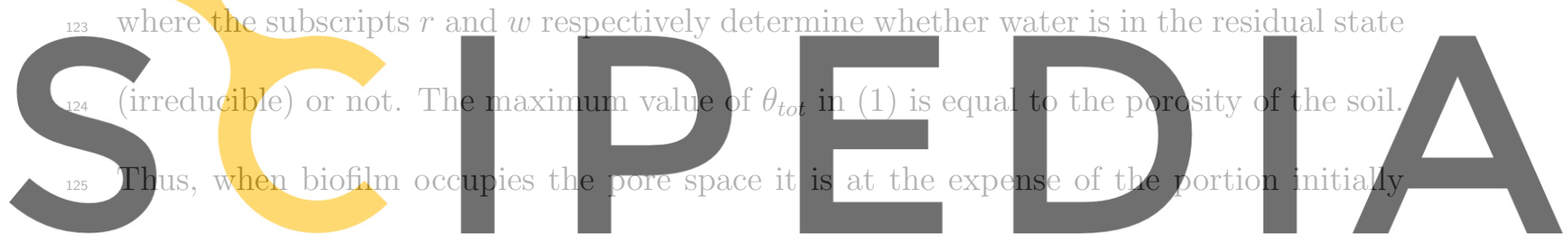

$$
\theta_{t o t}=\theta_{w, b i o}+\theta_{w, p m}+\theta_{r, b i o}+\theta_{r, p m}=\theta_{w}+\theta_{r},
$$

126 available for open-pore water. The presence of biofilm components other than water

Register for free at https//www.scipedia.com to download the version without the watermark (mainly solids particles), which would prevent the occurrence of full water saturation is

${ }_{128}$ neglected (details below).

\subsection{Water in Biofilms}

The complex structure and composition of biofilms [see Flemming and Wingender, 2010;

Or et al., 2007b; Picioreanu et al., 2004] demands the use of a multifaceted definition of

${ }_{131}$ the microbial phase, which is achieved from the six elements of PSSICO. First, a proper

${ }_{132}$ Identification of the microbial phase is needed (component "I" in the model). Second,

${ }_{133}$ the treatment of the microbial phase in the literature has several interpretations. Some 


$$
M_{b i o}(t)=M_{b a c t}(t)+M_{E P S}(t),
$$

where $M_{\text {bact }}, M_{E P S}$, and $M_{b i o}$ are respectively the masses of bacteria, EPS, and total biofilm, expressed in grams of dry mass per unit volume. The time variable $(t)$ denotes that biofilm composition may change with time.

${ }_{143}$ Concerning its structure, biofilms can be seen as a complex three-dimensional network

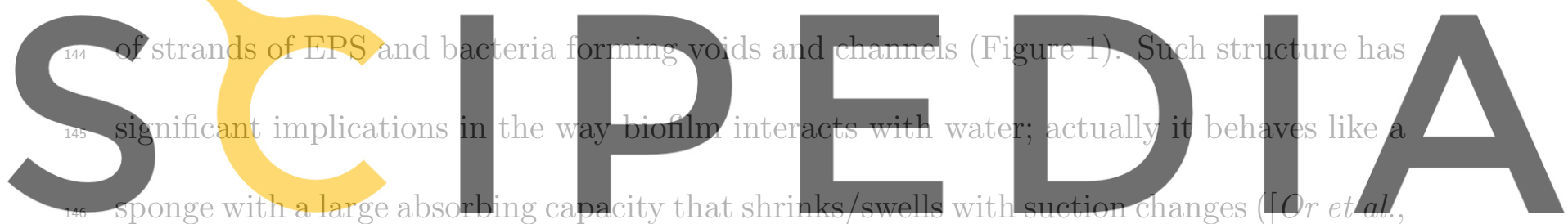

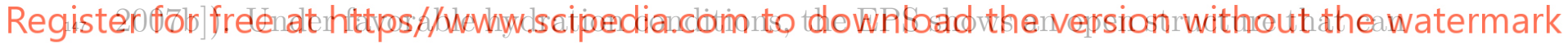

${ }_{143}$ hold up to 70 times its weight in water [Chenu, 1993]. On the contrary, biofilms respond

${ }_{149}$ by shrinking when suction increases becoming dense and amorphous, albeit holding a considerable amount of water. Such a mechanism enhances dehydration resistance and

151 fast recovery swelling after desiccation [Tamaru et al., 2005], minimizing the impact of

${ }_{152}$ dry conditions upon bacterial life [Or et al., 2007b].

${ }_{153}$ According to de Gennes [1979], the equilibrium mass ratio between a polymer and water 
${ }_{155}$ like a polymer, the volume of mobile water in biofilms is estimated by

$$
\theta_{w, b i o}^{*}\left(\psi, M_{b i o}\right)=\frac{M_{E P S}}{\rho_{w}} A \psi^{-B}
$$

${ }_{156}$ where $\psi$ is the matric suction (in $\mathrm{cm}$ ), $\rho_{w}$ the density of water, and $A, B$ are fitting ${ }_{157}$ experimental parameters. Rosenzweig et al. [2012] found values of $A=105.76$ and $B=$ 0.489 for pure xanthan $\left(\mathrm{C}_{35} \mathrm{H}_{49} \mathrm{O}_{29}\right)$, a natural polysaccharide widely used as an EPS analog [Chenu, 1993; Rosenzweig et al., 2012]. Nevertheless, the hydraulic properties of EPS depend on its specific composition. Particularly, xanthan depicts an outstanding retention capacity that is larger than other polysaccharides such as scleroglucan or dextran [Chenu, 1993]. Our model can effortless incorporate other type of relations (general or specific for a given study case) since it is not limited by working assumptions in (3-7).

${ }_{164}$ The boundless behavior of $\theta_{w, b i o}^{*}$ when $\psi$ approaches zero demands the imposition of

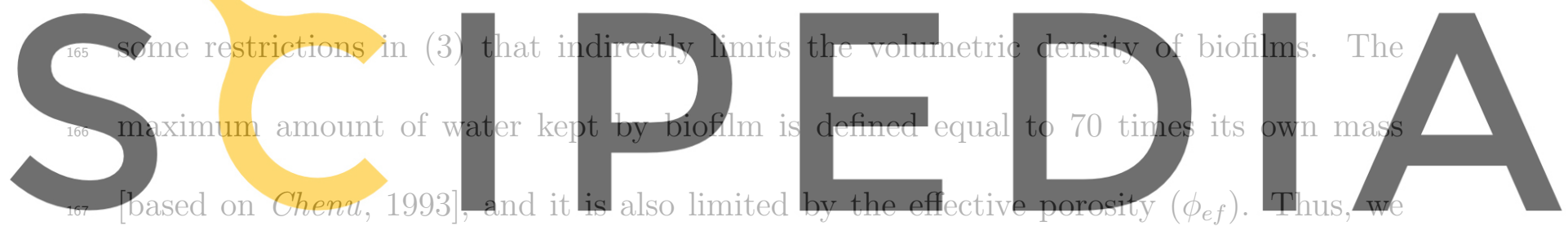

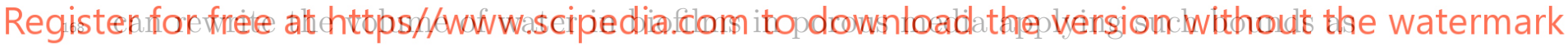

$$
\theta_{w, b i o}\left(\psi, M_{b i o}\right)=\min \left(\theta_{w, b i o}^{*}, 70 \frac{M_{b i o}}{\rho_{w}}, \phi_{e f}\right) .
$$

On the other hand, it seems logical to link $\theta_{r, b i o}$ to the composition of the biofilm. From the contributions of bacterial cells and EPS we obtain

$$
\theta_{r, b i o}\left(M_{b i o}\right)=0.8 \frac{M_{b a c t}}{\rho_{w}}+\frac{M_{E P S}}{\rho_{s}} \theta_{r, E P S}
$$

171 where $\rho_{s}$ is the bulk dry soil density and $\theta_{r, E P S}$ the residual water content for pure EPS.

${ }_{172}$ The first term in (5) considers the volume retained inside the body of bacteria. Water ${ }_{173}$ in cells is considered fully irreducible regardless of the environmental conditions, and it 
${ }_{174}$ is here quantified as $80 \%$ of the cellular volume [Cooke and Kuntz, 1974]. The remaining

\subsection{Water Flow through Biofilms} ${ }_{191} \lambda_{\mu}$, we postulate the following expression

$$
\lambda_{\mu}=\frac{1}{1-\left[\frac{\theta_{r, b i o}}{\theta_{w, b i o}+\theta_{r, b i o}}\right]^{\eta}},
$$

$$
\mu_{b i o}(\psi)=\lambda_{\mu}(\psi) \mu_{w},
$$

where $\lambda_{\mu}$ (always greater or equal to 1 ) specifies the increased resistance of water flowing through biofilm. Since there are no specific studies on the effect of shrinking/swelling in 
205 yielding

$$
f\left(r_{0}\right)=\frac{2 \sigma \cos (\beta)}{\gamma_{w} \pi r_{0}^{4}} \frac{d \theta_{w, p m}^{0}}{d \psi_{0}},
$$

$$
\psi_{0}=\frac{2 \sigma \cos (\beta)}{R_{0} \gamma_{w}}
$$

$$
\theta_{w, p m}^{0}\left(R_{0}\right)=\int_{R_{0, \min }}^{R_{0}} \pi r_{0}^{2} f\left(r_{0}\right) d r_{0}
$$

November $30,2016,12: 55 \mathrm{pm}$ and Soga, 2005]. The term $d \theta_{w, p m}^{0} / d \psi_{0}$ is the derivative of the SWRC expression. Despite maximum soil suction, which is generally considered in the order of $10^{5} \mathrm{~m}$ [e.g., Mitchell

where $R_{0, \min }$ is the minimum pore radius. This value may be estimated from (8) using the

(1)




$$
\theta_{w, p m}^{0}\left(\psi_{0}\right)=\phi_{e f}\left[1+\left[\alpha \psi_{0}\right]^{n}\right]^{\frac{1}{n}-1}
$$

$$
\frac{d \theta_{w, p m}^{0}\left(\psi_{0}\right)}{d \psi_{0}}=\alpha \phi_{e f}[1-n]\left[\alpha \psi_{0}\right]^{n-1}\left[1+\left[\alpha \psi_{0}\right]^{n}\right]^{\frac{1}{n}-2}
$$

However the presence of biomass reshapes the open porosity with the result that the content of open-pore water becomes

$$
\theta_{w, p m}(R)=\int_{R_{m i n}}^{R} \pi r^{2} f(r) d r
$$

where $f(r)$ is the new pore-size distribution of the bio-amended soil. The matric suction at which the transformed tube radius empties is still given by the capillary rise equation, written now as

$$
\psi=\frac{2 \sigma \cos (\beta)}{R \gamma_{w}}
$$

18 Then, the relation between (8) and (14) may be expressed as

$$
\psi=\frac{\psi_{0}}{X}
$$

19 where $X$ is a parameter that will be defined and discussed below.

The spatial competition between open-pore water and biofilm is illustrated in Figure 3. Note that when $\psi=\psi_{\max }$, the volume of water in the biofilm is minimum (residual) and $\theta_{w, b i o}=0$; but it rises as suction decreases, modifying the open porosity. The characteristics of the new pores depend on how biomass reshapes the capillary tubes. Some previous studies consider that biofilm forms a layer attached to the pore walls [e.g. Ezeuko et al., 2011; Mostafa and Van Geel, 2007; Rosenzweig et al., 2009]. The distribution patterns of this biofilm depend on whether it grows preferentially either in the smaller or 
${ }_{227}$ in the larger pores, or uniformly in all of them [see the lucid discussions in Bundt et al.,

$$
\begin{aligned}
& \theta_{t o t}\left(\psi, M_{b i o}\right)=\theta_{w, b i o}\left(\psi, M_{b i o}\right)+N X^{2} \theta_{w, p m}^{0}(X \psi)+\theta_{r, b i o}\left(M_{b i o}\right)+\theta_{r, p m} . \\
& \text { November } 30,2016,12: 55 \mathrm{pm}
\end{aligned}
$$

$$
f(r) d r=N f\left(r_{0}\right) d r_{0}
$$

(ii) the new tube radii are reduced by a positive real factor $X(\leq 1)$ with the result that

$$
r=X r_{0}
$$

Such a new combination of mechanisms allow the biofilm to show a relatively flexible architecture since it may be partially detached from the walls being located in the middle of the tubes cross-section. From a practical standpoint, this means that every single tube of radius $r_{0}$ is converted into $N$ equal cylindrical tubes of radius $r$, reproducing structural channels embedded in the biofilm matrix. The effect of this transformation may be observed in Figure 4.

Substituting (16) and (17) into (13), we have

$$
\theta_{w, p m}(R)=N X^{2} \int_{R_{0, m i n}}^{R_{0}} \pi r_{0}^{2} f\left(r_{0}\right) d r_{0}=N X^{2} \theta_{w, p m}^{0}\left(R_{0}\right)
$$

where, from (15), the pore-matrix water content is

$$
\theta_{w, p m}(\psi)=N X^{2} \theta_{w, p m}^{0}\left(\psi_{0}\right)=N X^{2} \theta_{w, p m}^{0}(X \psi),
$$

${ }_{24}$ and the retention curve for bio-amended soils may finally be written as 


$$
\phi_{e f}=\theta_{w, b i o}\left(\psi, M_{b i o}\right)+\theta_{w, p m}(\psi=0)
$$

must be fulfilled, the following relationship is therefore satisfied

$$
N X^{2}=1-\frac{\theta_{w, b i o}\left(\psi, M_{b i o}\right)}{\phi_{e f}},
$$

and the tube-reduction factor $X$ becomes

$$
X\left(\psi, M_{b i o}\right)=\sqrt{\frac{\phi_{e f}-\theta_{w, b i o}\left(\psi, M_{b i o}\right)}{N \phi_{e f}}} .
$$

Note that when both $X$ and $N X^{2}$ approach 1 the impact of biofilm is negligible. However, as the values of $\theta_{w, b i o}$ and/or $N$ increase, the water retention curve in (20) differs more and more from that of the biofilm-free soil.

Several considerations about this model should be made. The existence of a constant $X$ regardless of tube size means that biofilms proliferates in pores of all sizes. The amount of biomass in each tube is proportional to its squared radius and therefore the higher amounts of biomass are found in the larger tubes. These large tubes probably act as preferential paths through which nutrients may travel easily, promoting high growth rates. But at the same time, they also involve high velocities and high detachment effects [Thullner and Baveye, 2008], and are more likely to be exposed to drying periods [Bundt et al., 2001]. Despite the flow limitations in smaller pores, growth is still expected because some nutrients can be available through diffusion. Moreover, the potential entrapping of suspended biomass on pore throats [Vandevivere et al., 1995] may lead to additional accumulation in small tubes. On the other hand, the use of the parameters $N$ and $M_{b i o}$ may allow to better simulate the influence of the bioaccumulation since some mechanisms that were not 
${ }_{277}^{27}$ [Alaoui et al., 2011; Thullner and Baveye, 2008],

$$
Q_{\text {tube }}(r)=\nabla h \frac{\gamma_{w} \pi}{8 \mu_{w}} r^{4}
$$

${ }_{278}$ where $\nabla h$ is the hydraulic head gradient. Following Thullner and Baveye [2008], when a ${ }_{279}$ biomass layer of thickness $\delta$ coats the tube walls (24) is transformed to

$$
Q_{\text {tube }+b i o}(r)=\nabla h \frac{\gamma_{w} \pi}{8 \mu_{b i o}}\left[[r+\delta]^{4}-r^{4}\left[1-\lambda_{\mu}\right]\right] .
$$

${ }_{280}$ Nevertheless, the permeable biofilm coats all the tubes including those larger than $R$, ${ }_{281}$ which are devoid of open-pore water according to (14). The total flow rate may be 
${ }_{282}$ obtained by limiting the flow contribution to the area between $r$ and $r+\delta$ so that

$$
Q_{b i o}(r)=\nabla h \frac{\gamma_{w} \pi}{8 \mu_{b i o}}\left[[r+\delta]^{4}+r^{4}-2 r^{2}[r+\delta]^{2}\right]
$$

$$
N \pi[r+\delta]^{2}=\pi r_{0}^{2}
$$

being the relations between radii

$$
r+\delta=\frac{r_{0}}{\sqrt{N}}=\frac{r}{X \sqrt{N}}
$$

${ }_{28}$ The total flow rate in soil may be written as

$$
\begin{aligned}
q_{\text {soil }}(\psi) & =-K_{s} k_{r} \nabla h=\int_{R_{\min }}^{R} Q_{\text {tube }+ \text { bio }}(r) f(r) d r+\int_{R}^{R_{\max }} Q_{b i o}(r) f(r) d r \\
& =\int_{R_{0, \min }}^{R_{0}} Q_{\text {tube }+ \text { bio }}\left(X r_{0}\right) N f\left(r_{0}\right) d r_{0}+\int_{R_{0}}^{R_{0, \max }} Q_{b i o}\left(X r_{0}\right) N f\left(r_{0}\right) d r_{0},
\end{aligned}
$$

where $K_{s}$ is the real saturated hydraulic conductivity and $k_{r}$ the relative permeability.

Fon Finally, substituting (25) and (26) into (29), we obtain

$$
k_{r}(\psi)=\frac{\left[\frac{N^{-1}+N\left(\lambda_{\mu}-1\right) X^{4}}{\lambda_{\mu}}\right] \int_{X \psi_{\max }}^{X \psi} \frac{1}{\psi_{0}^{2}} \frac{d \theta_{w, p m}^{0}}{d \psi_{0}} d \psi_{0}+\left[\frac{N^{-1}+(N-2) X^{4}}{\lambda_{\mu}}\right] \int_{X \psi}^{X \psi_{\min }} \frac{1}{\psi_{0}^{2}} \frac{d \theta_{w, p m}^{0}}{d \psi_{0}} d \psi_{0}}{\int_{\psi_{\max }}^{\psi_{\min }} \frac{1}{\psi_{0}^{2}} \frac{d \theta_{w, p m}^{0}}{d \psi_{0}} d \psi_{0}},
$$

21 which under saturated conditions or when $X=0$ may be rewritten as

$$
k_{r}(\psi) \equiv \frac{N^{-1}+N\left(\lambda_{\mu}-1\right) X^{4}}{\lambda_{\mu}} .
$$

No2 Note that despite the fact that $\lambda_{\mu}$ and $X$ are suction-dependent parameters, both can 293 be moved out of the integrals in (30) since the suction is constant in the equation. 


\section{Comparison with Experimental Data}


339 of biofilms itself may reproduce changes under certain conditions. However, the same

340 model cannot reproduce the event observed in Rubol's soil. 
369 the tube walls.

\section{Impact of Bioclogging on the Soil Hydraulic Properties}

\subsection{Impact of Bioclogging on the SWRC}




\subsection{Impact of Bioclogging on Permeability}


${ }_{428}$ a certain emphasis on the biofilm architecture $(\mathrm{N})$. The more complex characterization of

${ }_{429}$ biofilms is at the expense of the pore space definition. Despite of that the pore intercon-

${ }_{430}$ nectivity is required to reflect the complexity of the multidimensional flow in real porous

${ }_{431}$ media, a simple analysis using our model already provides a rough estimation of the rela-

${ }_{432}$ tive permeability at some intermediate scale. The number of parameters studied and the need to define the flow through pore interconnections hamper determining whether such ${ }_{434}$ a simplification over- or underpredicts the real impact on soils. The lack of knowledge

${ }_{435}$ on this point together with the uncertainties illustrated in Figure 9 underline the need of ${ }_{436}$ further research.

Despite the importance of the transport of nutrients for biofilm growth, and the mobilization of contaminants in many fields, we consider it to be out of the scope of this paper. Here, we just state that the geometries discussed above also entail consequences

${ }_{440}$ in transport, as the interfaces through which mass is exchanged are redefined, modifying the exposure, nutrients availability, and removal rates.

\section{Conclusions}

The growth of biofilm in soils exerts a strong influence on hydraulic parameters, modi-

${ }_{443}$ fying the shape of the water retention curve and the relative permeability. We present a

${ }_{444}$ model that aims at improving our understanding of such a phenomenon. Our approach

${ }_{445}$ consists in modeling the local characteristics of soil as an ensemble of capillary tubes of different diameters. This simple (and widely used in biofilm-free soils) methodology is ex-

${ }_{447}$ tended by the incorporation of a biofilm composed of bacterial cells and EPS. Three main

${ }_{448}$ points are considered: i) biofilm alone is capable of holding large amounts of water and

${ }_{449}$ has particular hydraulic properties; ii) microbial phase undergoes changes in volume; and 
iii) biofilm is not a convex surface but a channeled complex geometry (which allows us to redefine the concept of tubes that are colonized by a biofilm with complex geometries). On the basis of these points, the new properties of the bio-colonized soil are derived yielding a set of analytical equations that account for the spatial competition between open-pore water and biofilm at pore-scale. First, the incorporation of channeled biofilm bodies that shrink/swell enables us to obtain a new pore-size distribution from which the soil-water retention curve is derived. Subsequently, the geometrical distribution of a permeable biofilm in tubes provides an approach to relative permeability. Such a flexible framework can incorporate with no effort other type of hypotheses regarding biofilm characteristics and distribution. Assumptions based on the tube theory vastly underestimate pore singularities, simplifying its geometry and interconnections and possibly underpredicting water content distribution and flow rates. The current model can be understood as a tool to isolate and better study the local impact of biofilms on the hydraulic properties.

The new expression for the SWRC is evaluated by the data of three bio-amended soils. The model can properly reproduce the displacement of the SWRC towards higher saturations. Moreover, a sensitivity analysis on both the SWRC and the relative permeability functions is performed in order to understand the role of the parameters presented. From it, we could explain how even small amounts of biofilm may fully reshape the pore network leading to significant changes in hydraulic properties. Results indicate that the morphology, the spatial distribution of biomass and the EPS swelling and shrinking characteristics are key factors controlling the properties of bio-amended soils. The number of hypotheses included in the model enhances the need for a sound analysis of these properties of 
${ }_{472}$ biofilms, as they play a major role in the overall soil behavior and therefore they should

${ }_{473}$ be included somehow in biofilm modeling.

Acknowledgments. The research leading to these results has received funding from 475 the European Union FP7 under grant agreement no 619120 (Demonstrating Man${ }_{476}$ aged Aquifer Recharge as a Solution to Water Scarcity and Drought MARSOL), and ${ }_{477}$ PCOFUND-GA-2008-226070. Additional support was provided by the Spanish Ministry of Economy and Competitiveness (project SCARCE, ref. CSD2009-00065), and the Min${ }_{479}$ istry of Science and Innovation (project FEAR, ref. CGL2012-38120; and the research ${ }_{480}$ fellowship FPI BES-2013-063419). XS acknowledges support from the ICREA Academia ${ }_{481}$ Program. We would like to thank three anonymous reviewers and the associate editor ${ }_{482}$ for their constructive comments. We also thank George von Knorring for reviewing the ${ }_{483}$ English of an early version of the manuscript. Data can be requested by contacting the ${ }_{484}$ corresponding author.

\section{References}

${ }_{485}$ Abdel-Waly, A. (2013), Laboratory Study On Activating Indigenous Microorganisms ${ }_{486}$ to Enhance Oil Recovery, Journal of Canadian Petroleum Technology, 38(02), doi: 10.2118/99-02-05.

Alaoui, A., J. Lipiec, and H. H. Gerke (2011), A review of the changes in the soil pore system due to soil deformation: A hydrodynamic perspective, Soil and Tillage Research, 115-116, 1-15, doi:10.1016/j.still.2011.06.002.

Baveye, P., P. Vandevivere, B. L. Hoyle, P. C. DeLeo, and D. S. de Lozada (1998), Environmental Impact and Mechanisms of the Biological Clogging of Saturated Soils and 
Aquifer Materials, Critical Reviews in Environmental Science and Technology, 28(2), 123-191, doi:10.1080/10643389891254197.

Beckett, C., and C. Augarde (2013), Prediction of soil water retention properties using pore-size distribution and porosity, Canadian Geotechnical Journal, 450(April), 435450, doi:10.1139/cgj-2012-0320.

Billings, N., A. Birjiniuk, T. S. Samad, P. S. Doyle, and K. Ribbeck (2015), Material properties of biofilmsa review of methods for understanding permeability and mechanics, Reports on Progress in Physics, 78(3), 036,601, doi:10.1088/0034-4885/78/3/036601.

Bozorg, A., I. D. Gates, and A. Sen (2015), Using bacterial bioluminescence to evaluate the impact of biofilm on porous media hydraulic properties, Journal of Microbiological Methods, 109, 84-92, doi:10.1016/j.mimet.2014.11.015.

Brooks, R. H., and A. T. Corey (1964), Hydraulic properties of porous media, Hydrology papers Colorado State University, 3.

Bundt, M., F. Widmer, M. Pesaro, J. Zeyer, and P. Blaser (2001), Preferential flow paths: Biological 'hot spots' in soils, Soil Biology and Biochemistry, 33(6), 729-738.

Burdine, N. (1953), Relative Permeability Calculations From Pore Size Distribution Data, doi:10.2118/225-G.

Carsel, R., and R. Parrish (1988), Developing joint probability distributions of soil water retention characteristics, Water Resources Research, 24(5), 755-769.

Castegnier, F., N. Ross, R. P. Chapuis, L. Deschênes, and R. Samson (2006), Long-term persistence of a nutrient-starved biofilm in a limestone fracture., Water research, 40(5), 925-34, doi:10.1016/j.watres.2005.12.038. 
Chenu, C. (1993), Clay-or sand-polysaccharide associations as models for the interface between micro-organisms and soil: water related properties and microstructure, Geoderma, 56(1-4), 143-156.

Christensen, T. H., P. L. Bjerg, S. A. Banwart, R. Jakobsen, G. Heron, and H.-J. Albrechtsen (2000), Characterization of redox conditions in groundwater contaminant plumes, Journal of Contaminant Hydrology, 45(3-4), 165-241.

Clement, T., B. Hooker, and R. Skeen (1996), Macroscopic models for predicting changes in saturated porous media properties caused by microbial growth, Groundwater, $34(5)$, $934-942$.

Cooke, R., and I. D. Kuntz (1974), The properties of water in biological systems, Annual Review of Biophysics and Bioengineering, 3, 95-126, doi: 10.1146/annurev.bb.03.060174.000523.

Cunningham, A., R. Gerlach, L. Spangler, and A. Mitchell (2009), Microbially enhanced geologic containment of sequestered supercritical CO2, Energy Procedia, 1(1), 32453252, doi:10.1016/j.egypro.2009.02.109.

Cunningham, A. B., w. G. Characklis, F. Abedeen, and D. Crawford (1991), Influence of biofilm accumulation on porous media hydrodynamics, Environmental Science and Technology, 25 (7), 1305-1311.

Davit, Y., H. Byrne, J. Osborne, J. Pitt-Francis, D. Gavaghan, and M. Quintard (2013), Hydrodynamic dispersion within porous biofilms, Physical Review E - Statistical, Nonlinear, and Soft Matter Physics, 87(1), 24-29, doi:10.1103/PhysRevE.87.012718.

De Beer, D., and A. Schramm (1999), Micro-environments and mass transfer phenomena in biofilms studied with microsensors, in Water Science and Technology, vol. 39, pp. 
173-178, doi:10.1016/S0273-1223(99)00165-1.

de Gennes, P.-G. (1979), Scaling Concepts in Polymer Physics, Cornell University Press. De Muynck, W., N. De Belie, and W. Verstraete (2010), Microbial carbonate precipitation in construction materials: A review, Ecological Engineering, 36(2), 118-136, doi:10.1016/j.ecoleng.2009.02.006.

DeJong, J., K. Soga, and E. Kavazanjian (2013), Biogeochemical processes and geotechnical applications: progress, opportunities and challenges, Géotechnique, 63(4), 287-301.

Donlan, R. M. (2002), Biofilms: Microbial life on surfaces, doi:10.3201/eid0809.020063.

Dupin, H. J., P. K. Kitanidis, and P. L. McCarty (2001), Pore-scale modeling of biological clogging due to aggregate expansion: A material mechanics approach, Water Resources Research, 37(12), 2965-2979, doi:10.1029/2001WR000306.

Ehrlich, H. L. (1999), Microbes as Geologic Agents: Their Role in Mineral Formation, Geomicrobiology Journal, 16(2), 135-153, doi:10.1080/014904599270659.

Engesgaard, P., D. Seifert, and P. Herrera (2006), Bioclogging in porous media: tracer studies, in Riverbank Filtration Hydrology, vol. 60, pp. 93-118, Springer Netherlands.

Ezeuko, C., A. Sen, A. Griogoryan, and G. I.D. (2011), Pore-network modeling of biofilm evolution in porous media, Biotechnology and Bioengineering, 108(10), 2413-2423, doi: 10.1002/bit.23183.

Fenchel, T. (2002), Microbial behavior in a heterogeneous world, Science, 296(5570), 1068-1071, doi:10.1126/science.1070118.

Flemming, H.-C., and J. Wingender (2010), The biofilm matrix, Nature reviews. Microbiology, 8(9), 623-33, doi:10.1038/nrmicro2415. 
Freixa, A., S. Rubol, A. Carles-Brangarí, D. Fernàndez-Garcia, A. Butturini, X. SanchezVila, and A. M. Romaní (2016), The effects of sediment depth and oxygen concentration on the use of organic matter : An experimental study using an in fi ltration sediment tank, Science of the Total Environment, 540, 20-31, doi:10.1016/j.scitotenv.2015.04.007.

Hand, V. L., J. R. Lloyd, D. J. Vaughan, M. J. Wilkins, and S. Boult (2008), Experimental studies of the influence of grain size, oxygen availability and organic carbon availability on bioclogging in porous media, Environmental Science $\&$ Technology, 42(5), 14851491.

Kennedy, P. L., and P. J. Van Geel (2001), Impact of density on the hydraulics of peat filters, Canadian Geotechnical Journal, 38, 1213-1219, doi:10.1139/t01-047.

Kim, J., H. Choi, and Y. Pachepsky (2010), Biofilm morphology as related to the porous media clogging, Water Research, 44(4), 1193-1201, doi:10.1016/j.watres.2009.05.049.

Laspidou, C. S., and B. E. Rittmann (2004), Modeling the development of biofilm density including active bacteria, inert biomass, and extracellular polymeric substances, Water Research, 38(14-15), 3349-3361, doi:10.1016/j.watres.2004.04.037.

Lawrence, J. R., D. R. Korber, B. D. Hoyle, J. W. Costerton, and D. E. Caldwell (1991), Optical sectioning of microbial biofilms, Journal of Bacteriology, 173, 6558-6567.

Likos, W., and R. Jaafar (2013), Pore-scale model for water retention and fluid partitioning of partially saturated granular soil, Journal of Geotechnical and Geoenvironmental Engineering, 139(5), 724-737, doi:10.1061/(ASCE)GT.1943-5606.0000811.

Mauclaire, L., A. Schürmann, and F. Mermillod-Blondin (2006), Influence of hydraulic conductivity on communities of microorganisms and invertebrates in porous media: a case study in drinking water slow sand filters, Aquatic Sciences, 68(1), 100-108, doi: 
10.1007/s00027-005-0811-4.

Mitchell, J. K., and K. Soga (2005), Soil Composition and Engineering Properties, in Fundamentals of Soil Behavior, pp. 83-108, CBS Publishers \& Distributors Pvt. Ltd.

Morris, R. H., M. I. Newton, P. R. Knowles, M. Bencsik, P. A. Davies, P. Griffin, and G. McHale (2011), Analysis of clogging in constructed wetlands using magnetic resonance, The Analyst, 136, 2283-2286, doi:10.1039/c0an00986e.

Mostafa, M., and P. Van Geel (2012), Validation of a Relative Permeability Model for Bioclogging in Unsaturated Soils, Vadose Zone Journal, 11 (1), doi:10.2136/vzj2011.0044.

Mostafa, M., and P. J. Van Geel (2007), Conceptual Models and Simulations for Biological Clogging in Unsaturated Soils, Vadose Zone Journal, 6(1), 175, doi: $10.2136 / \operatorname{vzj} 2006.0033$

Mualem, Y. (1976), A new model for predicting the hydraulic conductivity of unsaturated porous media, Water Resources Research, 12(3).

Or, D., B. Smets, and J. Wraith (2007a), Physical constraints affecting bacterial habitats and activity in unsaturated porous mediaa review, Advances in Water Resources, 30(67), 1505-1527.

Or, D., S. Phutane, and A. Dechesne (2007b), Extracellular polymeric substances affecting pore-scale hydrologic conditions for bacterial activity in unsaturated soils, Vadose Zone Journal, 6(2), 298-305, doi:10.2136/vzj2006.0080.

Pedretti, D., M. Barahona-Palomo, B. Diogo, D. Fernàndez-Garcia, X. Sanchez-Vila, and D. M. Tartakovsky (2012), Probabilistic analysis of maintenance and operation of artificial recharge ponds, Advances in Water ..., 36(April 2011), 23-35, doi: 10.1016/j.advwatres.2011.07.008. 
Peña-Cabriales, J. J., and M. Alexander (1979), Survival of Rhizobium in Soils Undergoing Drying, Soil Science Society of America Journal, 43(5), 962, doi: 10.2136/sssaj1979.03615995004300050030x.

Picioreanu, C., J. Xavier, and M. van Loosdrecht (2004), Advances in mathematical modeling of biofilm structure, Biofilms, 1(4), 337-349, doi:10.1017/S1479050505001572.

Pintelon, T. R. R., C. Picioreanu, M. C. M. van Loosdrecht, and M. L. Johns (2012), The effect of biofilm permeability on bioclogging of porous media, Biotechnology and Bioengineering, 109(4), 1031-1042, doi:10.1002/bit.24381.

Qin, C.-Z., and S. M. Hassanizadeh (2015), Pore-Network Modeling of Solute Transport and Biofilm Growth in Porous Media, Transport in Porous Media, 110(3), 345-367, doi:10.1007/s11242-015-0546-1.

Rebata-Landa, V., and J. C. Santamarina (2012), Mechanical Effects of Biogenic Nitrogen Gas Bubbles in Soils, doi:10.1061/(ASCE)GT.1943-5606.0000571.

Rittmann, B. (1993), The significance of biofilms in porous media, Water Resources Research, 29(7), 2195-2202.

Roane, T. M., K. A. Reynolds, R. M. Maier, and I. L. Pepper (2009), Environmental Microbiology, 9-36 pp., Elsevier, doi:10.1016/B978-0-12-370519-8.00002-X.

Rockhold, M., R. Yarwood, M. Niemet, P. Bottomley, and J. Selker (2002), Considerations for modeling bacterial-induced changes in hydraulic properties of variably saturated porous media, Advances in Water Resources, 25(5), 477-495.

Rodríguez-Escales, P., A. Folch, B. M. van Breukelen, G. Vidal-Gavilan, and X. SanchezVila (2016), Modeling long term Enhanced in situ Biodenitrification and induced heterogeneity in column experiments under different feeding strategies, Journal of Hydrology, 
538, 127-137, doi:10.1016/j.jhydrol.2016.04.012.

Rosenzweig, R., U. Shavit, and A. Furman (2009), The influence of biofilm spatial distribution scenarios on hydraulic conductivity of unsaturated soils, Vadose Zone Journal, 8(4), 1080, doi:10.2136/vzj2009.0017.

Rosenzweig, R., U. Shavit, and A. Furman (2012), Water retention curves of biofilmaffected soils using xanthan as an analogue, Soil Science Society of America Journal, $76(1), 61-69$, doi:10.2136/sssaj.

Rosenzweig, R., A. Furman, and U. Shavit (2013), A channel network model as a framework for characterizing variably saturated flow in biofilm-affected soils, Vadose Zone Journal, 12(2), doi:10.2136/vzj2012.0079.

Rosenzweig, R., A. Furman, C. Dosoretz, and U. Shavit (2014), Modeling biofilm dynamics and hydraulic properties in variably saturated soils using a channel network model, Water Resources Research, 50, 5678-5697, doi:10.1002/ 2013WR015211.

Ross, N., R. Villemur, L. Deschênes, and R. Samson (2001), Clogging of a limestone fracture by stimulating groundwater microbes, Water Research, 35, 2029-2037, doi: 10.1016/S0043-1354(00)00476-0.

Rubol, S., A. Freixa, A. Carles-Brangarí, D. Fernàndez-Garcia, A. M. Romaní, and X. Sanchez-Vila (2014), Connecting bacterial colonization to physical and biochemical changes in a sand box infiltration experiment, Journal of Hydrology, 517, 317-327, doi:10.1016/j.jhydrol.2014.05.041.

Samsó, R., and J. García (2014), The Cartridge Theory: a description of the functioning of horizontal subsurface flow constructed wetlands for wastewater treatment, based on modelling results., The Science of the Total Environment, 473-474, 651-8, 
doi:10.1016/j.scitotenv.2013.12.070.

Seki, K., T. Miyazaki, and M. Nakano (1998), Effects of microorganisms on hydraulic conductivity decrease in infiltration, European Journal of Soil Science, 49(2), 231-236.

Selker, J. S., J. T. McCord, and C. K. Keller (1999), Vadose Zone Processes, 352 pp., CRC Press.

Soleimani, S., P. J. Van Geel, O. B. Isgor, and M. B. Mostafa (2009), Modeling of biological clogging in unsaturated porous media, Journal of Contaminant Hydrology, 106 (1-2), 39-50, doi:10.1016/j.jconhyd.2008.12.007.

Stewart, P. S. (2012), Mini-review: convection around biofilms., Biofouling, 28(2), 187-98, doi:10.1080/08927014.2012.662641.

Stoodley, P., D. DeBeer, and Z. Lewandowski (1994), Liquid flow in biofilm systems, Applied and Environmental Microbiology, 60(8), 2711-2716.

Stoodley, P., K. Sauer, D. G. Davies, and J. W. Costerton (2002), Biofilms as complex differentiated communities., Annual review of microbiology, 56, 187-209, doi: 10.1146/annurev.micro.56.012302.160705.

Tamaru, Y., Y. Takani, T. Yoshida, and T. Sakamoto (2005), Crucial role of extracellular polysaccharides in desiccation and freezing tolerance in the terrestrial cyanobacterium Nostoc commune, Applied and Environmental Microbiology, 71(11), 7327-7333, doi: 10.1128/AEM.71.11.7327-7333.2005.

Taylor, S. W., and P. R. Jaffé (1990), Biofilm growth and the related changes in the physical properties of a porous medium: 1. Experimental investigation, Water Resources Research, 26(9), 2153-2159, doi:10.1029/WR026i009p02153. 
Taylor, S. W., P. Milly, and P. R. Jaffe (1990), Biofilm Growth and the Related Changes in the Physical Properties of a Porous Medium. 2. Permeability, Water Resources Research WRERAQ, 26(9).

Thullner, M. (2010), Comparison of bioclogging effects in saturated porous media within one-and two-dimensional flow systems, Ecological Engineering, 36(2), 176-196, doi: 10.1016/j.ecoleng.2008.12.037.

Thullner, M., and P. Baveye (2008), Computational pore network modeling of the influence of biofilm permeability on bioclogging in porous media, Biotechnology and Bioengineering, 99(6), 1337-1351, doi:10.1002/bit.21708.

Van Cuyk, S., R. Siegrist, A. Logan, S. Masson, E. Fischer, and L. Figueroa (2001), Hydraulic and purification behaviors and their interactions during wastewater treatment in soil infiltration systems, Water Research, 35, 953-964, doi:10.1016/S00431354(00)00349-3.

van Genuchten, M. T. (1980), A closed-form equation for predicting the hydraulic conductivity of unsaturated soils, Soil science society of America Journal, 44(5).

Vandevivere, P., and P. Baveye (1992a), Saturated Hydraulic Conductivity Reduction Caused by Aerobic Bacteria in Sand Columns, Soil Science Society of America Journal, 56, 1-13, doi:10.2136/sssaj1992.03615995005600010001x.

Vandevivere, P., and P. Baveye (1992b), Effect of bacterial extracellular polymers on the saturated hydraulic conductivity of sand columns, Applied and Environmental Microbiology, 58(5), 1690-1698.

Vandevivere, P., P. Baveye, D. Sanchez de Lozaa, and P. DeLeo (1995), Microbial clogging of saturated soils and aquifer materials: Evaluation of mathematical models, Water 
Resources Research, 31(9), 2173-2180.

Volk, E., S. C. Iden, A. Furman, W. Durner, and R. Rosenzweig (2016), Biofilm effect on soil hydraulic properties: Experimental investigation using soil-grown real biofilm, Water Resources Research, pp. 1-20, doi:10.1002/2016WR018866.

Wagner, M., D. Taherzadeh, C. Haisch, and H. Horn (2010), Investigation of the mesoscale structure and volumetric features of biofilms using optical coherence tomography., Biotechnology and bioengineering, 107(5), 844-53, doi:10.1002/bit.22864.

Wilking, J. N., T. E. Angelini, A. Seminara, M. P. Brenner, and D. a. Weitz (2011), Biofilms as complex fluids, MRS Bulletin, 36(05), 385-391, doi:10.1557/mrs.2011.71.

Yarwood, R., M. Rockhold, M. Niemet, J. Selker, and P. Bottomley (2006), Impact of microbial growth on water flow and solute transport in unsaturated porous media, Water Resources Research, 42(10), doi:10.1029/2005WR004550.

Young, I. M., and J. W. Crawford (2004), Interactions and self-organization in the soilmicrobe complex., Science, 304, 1634-1637, doi:10.1126/science.1097394.

Zhang, T. C., Y. Fu, P. L. Bishop, M. Kupferle, S. FitzGerald, H. H. Jiang, and C. Harmer (1995), Transport and biodegradation of toxic organics in biofilms, Journal of Hazardous Materials, 41, 267-285, doi:10.1016/0304-3894(94)00118-Z.

Zhong, X., and Y. Wu (2013), Bioclogging in porous media under continuous-flow condition, Environmental Earth Sciences, 68(8), 2417-2425, doi:10.1007/s12665-012-1926-2. 
Figure 1. Images of biofilms showing heterogeneous structure. Left: mature biofilm forming voids and channels between two soil grains [modified from Hand et al., 2008]. Right: Stained EPS and bacteria developed on a steel surface [modified from Donlan, 2002]. 
Figure 2. Estimate of $\lambda_{\mu}$ due to changes in the water content of the biofilm caused by swelling/shrinking processes, based on (7). 
Figure 3. Solid (mineral), biofilm, water and air phases present in a bio-amended soil under variably suction stress. Left: distribution of the different phases within the total volume. Right: cross-sections of the capillary tubes, displaying the spatial distribution of air, open-pore water and water in biofilm. For each suction value, only the tubes (of the newly defined pore-matrix) smaller than $R$ remain fully saturated while the others have the specific amount of water relative to the volume of biofilm they content. 
Figure 4. Sketch showing how $N$ modifies the pore-size distribution of the porous medium. This has a direct impact on the volumetric water content. The top scenario depicts the behavior of a biofilm-free soil whereas the others reproduce the changes in the distribution of phases with $N . \theta_{w, b i o}$ and $\psi$ remain constant in all cases. 
Figure 5. Sketch of the geometrical distribution of biofilm and its impact upon flow. The permeability approach requires a slight modification of the geometry. Symmetry around the central axis is recovered while the areas of the phases are still conserved. Left: A tube of radius $r_{0}$ is redefined as a tube of radius $r+\delta$ for mathematical convenience. Right: a single tube of radius $r_{0}$ is transformed into four new pore-matrix tubes $(N=4)$ of radius $r+\delta$. Green areas are microbial phase cross-sections through which water flows. When $r>R$ (left case), despite flow is not allowed through the pore-matrix, the microbial phase does contribute to flow. 
Figure 6. Comparison of bioclogging models with experimental data reported by Rosenzweig et al. [2012], left figure, and Rubol et al. [2014], right figure. The bioclogging models presented include the BCC-PSSICO model, the macroscopic model of Rockhold et al. [2002] and the linear superposition model by Rosenzweig et al. [2012]. 
Figure 7. Effect of $N$ on the water holding capacities of the composite medium (left, in black), distinguishing between water in the pore-matrix (middle, in brown) and pure biofilm (right, in green). The mass fraction of EPS is assumed equal to $5 \cdot 10^{-3} \mathrm{~g} \mathrm{EPS} / \mathrm{cm}^{3}$ in order to isolate the effect of $N$. 
Figure 8. Effect of $M_{b i o}$ on the volumetric water content for $N=1$ (top) and $N=10$ (bottom), distinguishing between water in the pore-matrix (middle, in brown) and pure biofilm (right, in green). The mass of biofilm is expressed in $\mathrm{g} \mathrm{EPS} / \mathrm{cm}^{3}$. 
Figure 9. Effect of different combinations of $N$, and $M_{b i o}$ on the relative permeability for soils. Lines correspond to the biofilm-free soil (red line), and five theoretical bio-amended soils. The mass of biofilm is expressed in $\mathrm{g}$ EPS $/ \mathrm{cm}^{3}$. Top: the dynamic viscosity of water flowing through biofilms is considered as constant. Regardless of the swelling status, biofilm is defined as impermeable $\left(\lambda_{\mu}=\infty\right)$, semi-permeable $\left(\lambda_{\mu}=5\right)$, or fully-permeable $\left(\lambda_{\mu}=1\right)$. Bottom: the parameter accounting for the viscosity changes when biofilm shrinks/swells is evaluated. 
Table 1. Parameters of the van Genuchten model and of the amount of biomass. SWRC parameters are obtained from Rosenzweig et al. [2012] and using a nonlinear regression on data from Rubol et al. [2014]. $\theta_{r}$ in Rubol's soil is evaluated using a linear superposition equation based on the weighted average of the grain-size fractions and hydraulic parameters in Carsel and Parrish [1988]. The biological parameters are the estimated values of bacteria, EPS and total biofilm.

\begin{tabular}{cccccccccc}
\hline Soil & $\begin{array}{c}\text { Biomass } \\
{[\%]}\end{array}$ & $\begin{array}{c}\phi_{\text {ef }} \\
{[-]}\end{array}$ & $\begin{array}{c}\theta_{r} \\
{[-]}\end{array}$ & $\begin{array}{c}\mathrm{n} \\
{\left[\mathrm{cm}^{-1}\right]}\end{array}$ & $\begin{array}{c}\alpha \\
{[-]}\end{array}$ & $\begin{array}{c}\rho_{s} \\
{\left[\mathrm{~g} / \mathrm{cm}^{3}\right]}\end{array}$ & $\begin{array}{c}M_{\text {bact }} \\
{\left[\mathrm{g} / \mathrm{cm}^{3}\right]}\end{array}$ & $\begin{array}{c}M_{E P S} \\
{\left[\mathrm{~g} / \mathrm{cm}^{3}\right]}\end{array}$ & $\begin{array}{c}M_{\text {bio }} \\
{\left[\mathrm{g} / \mathrm{cm}^{3}\right]}\end{array}$ \\
\hline Rosenzweig & 0 & 0.402 & 0.026 & 2.32 & 0.042 & 1.56 & 0 & 0 & 0 \\
\hline Rosenzweig & 0.25 & 0.420 & 0.048 & 2.11 & 0.031 & - & 0 & $3.91 \cdot 10^{-3}$ & $3.91 \cdot 10^{-3}$ \\
\hline Rosenzweig & 1 & 0.480 & 0.054 & 1.89 & 0.022 & - & 0 & $1.576 \cdot 10^{-2}$ & $1.576 \cdot 10^{-2}$ \\
\hline Rubol & 0 & 0.207 & 0.044 & 1.63 & 0.087 & 1.5 & 0 & 0 & 0 \\
\hline Rubol & 0.1 & 0.222 & 0.045 & 2.18 & 0.029 & - & $1.519 \cdot 10^{-3}$ & $1.683 \cdot 10^{-5}$ & $1.536 \cdot 10^{-3}$ \\
\hline
\end{tabular}


Table 2. Physical properties of water.

\begin{tabular}{ccccc}
\hline $\begin{array}{c}\sigma \\
{[N / \mathrm{cm}]}\end{array}$ & $\begin{array}{c}\cos (\beta) \\
{[-]}\end{array}$ & $\begin{array}{c}\gamma_{w} \\
{\left[N / \mathrm{cm}^{3}\right]}\end{array}$ & $\begin{array}{c}\rho_{w} \\
{\left[\mathrm{~g} / \mathrm{cm}^{3}\right]}\end{array}$ & $\begin{array}{c}\mu_{w} \\
{\left[\mathrm{sN} / \mathrm{cm}^{2}\right]}\end{array}$ \\
\hline $7.15 \cdot 10^{-4}$ & 1 & $9.789 \cdot 10^{-3}$ & 0.998 & $1.002 \cdot 10^{-7}$ \\
\hline
\end{tabular}


Figure 1. 


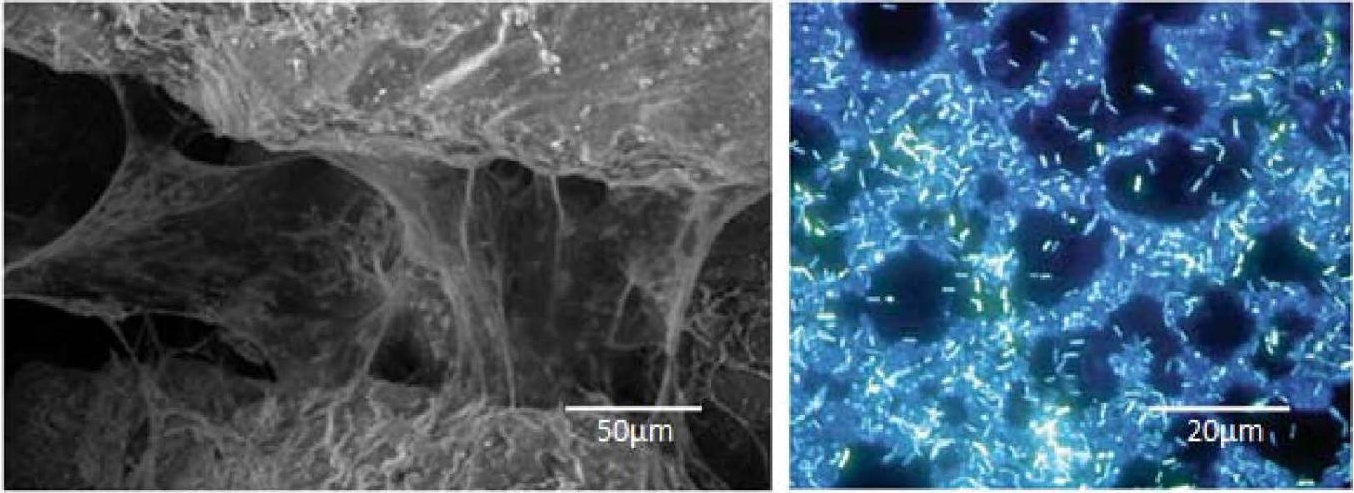


Figure 2. 


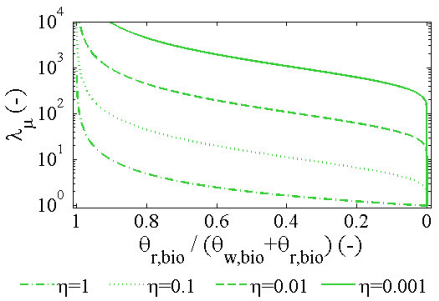


Figure 3. 


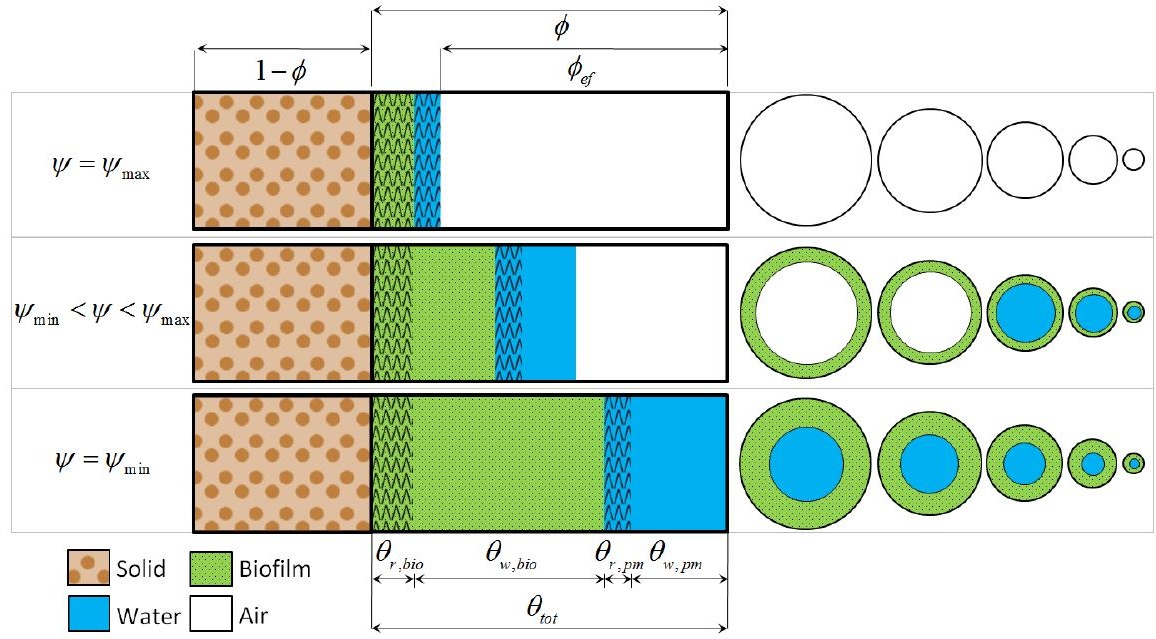


Figure 4. 


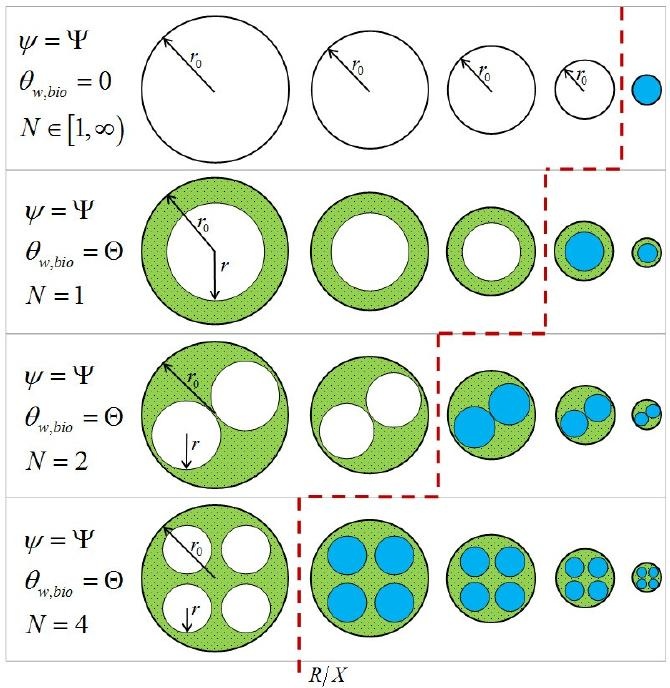


Figure 5. 


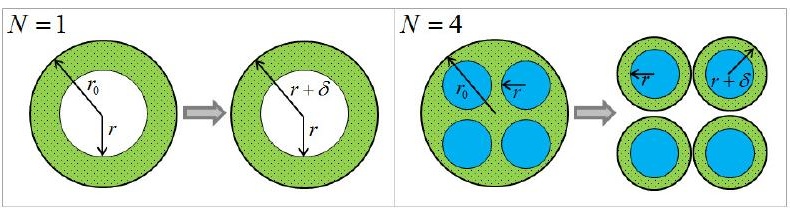


Figure 6. 


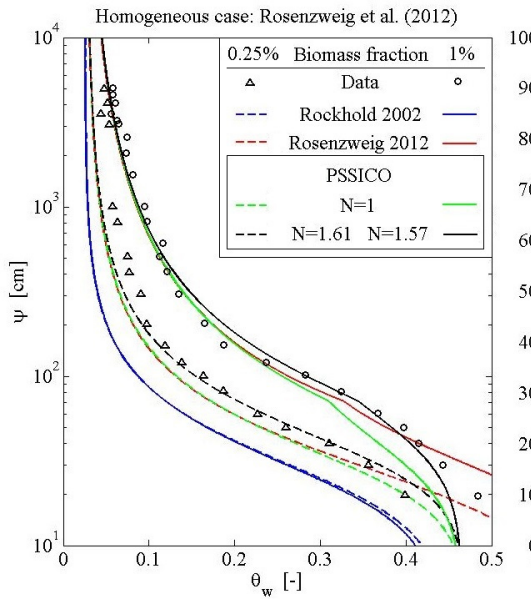

Heterogeneous case: Rubol et al. (2014)

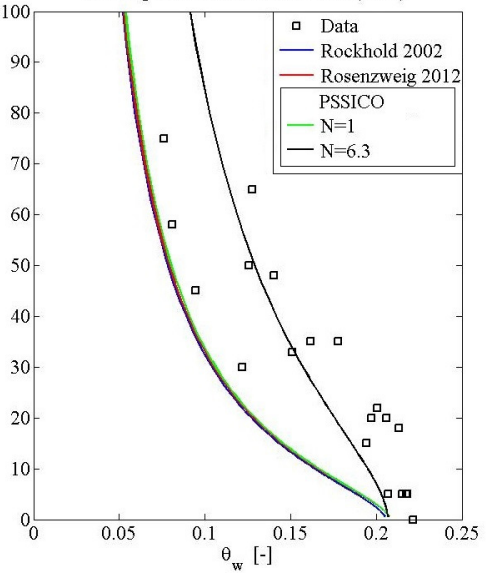


Figure 7. 


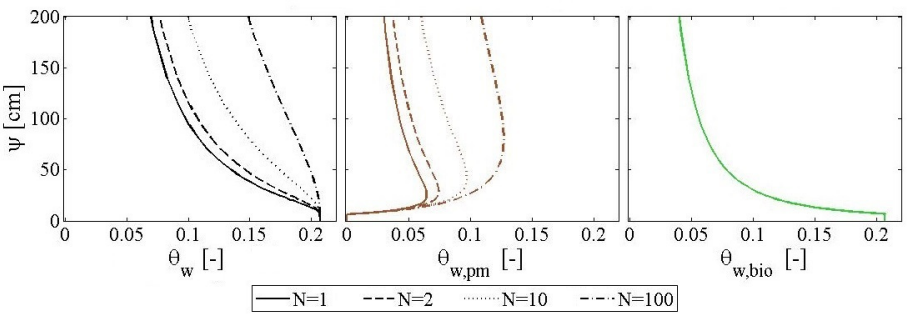


Figure 8. 
Figure 9. 


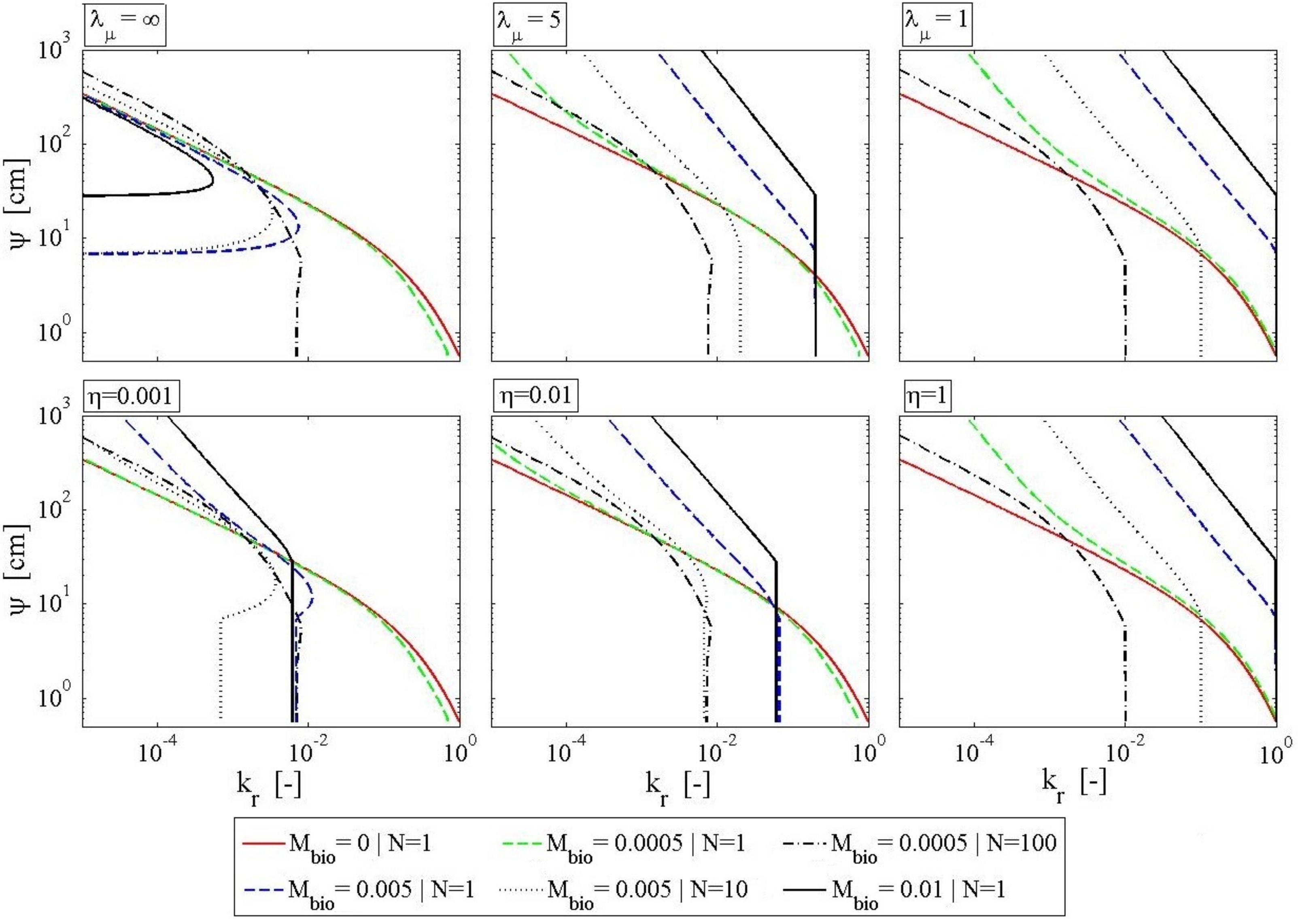

